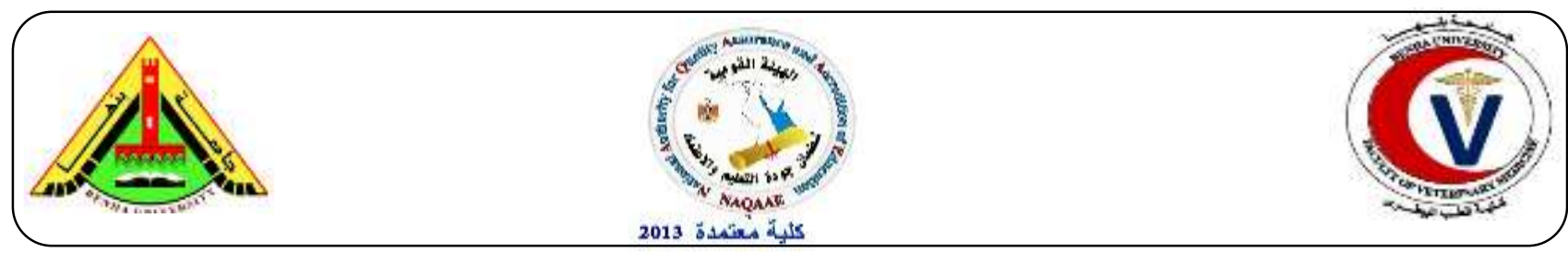

\title{
The impact of $\beta$ glucan on the Immune Response of Broiler Chickens Vaccinated with NDV and AI H9V Vaccines
}

\author{
Ashraf A. Abd El-Tawab', Omnia Mohammed Elnaggar ${ }^{1}$, Ashgan Fahmi Elsissi ${ }^{2}$ \\ ${ }^{1}$ Department of Bacteriology, Immunology and Mycology, Faculty of Veterinary Medicine, Benha University \\ ${ }^{2}$ Department of Immunology, Animal Health Research Institute, Dokki, Giza, Egypt
}

\section{A B S T R A C T}

To evaluate the effects of $\beta$ glucan on innate and adaptive immune responses of broilers vaccinated for routine vaccination with Newcastle disease virus (NDV) and Avian Influenza H9N2 (AIV) vaccines. A total of 180 chicks of one-day old Hubbard local breedThey were divided into three groups (sixty chicks for each group). The first group fed with normal broiler diet without any additives and served as control group, while the other two groups consumed diets contained $(200 \mathrm{mg}, 400 \mathrm{mg}$ pure $\beta$ glucan $/ \mathrm{kg}$ diet respectively for 42 days of the experimental period. We noticed that, the administration of $\beta$ glucan to broiler chickens early in life increased significantly $(p<0.05)$ the nitric oxide levels, lysozyme activity, phagocytic activity, and phagocytic index , inaddition improved the oxidative state by decreasing malondialdehyde (MDA) and increasing glutathione (GSH) and. High concentration of $\beta$ glucan improves immune response to NDV and AIV vaccines.

Keywords: $\beta$ glucan, Immune response, Broiler chickens NDV, AIV, Vaccines.

Received: 17 June 2019, Accepted: 21 July 2019 (http://www.bvmj.bu.edu.eg) (BVMJ-36(2): 100-108, 2019)

\section{INTRODUCTION}

Poultry production is a growing and economically an important industry, and therefore, the interest in improving the production results through improved health of the poultry. Fungal biotechnology greatly assists human particularly in immune modulation, and prebiotic $\beta$ glucans have been characterized as "biological response modifiers" (Huff et al., 2016; Leung et al., 2010; Volman et al., 2018, Novak and Vetvicka, 2017; Soltanian et al., 2009). $\beta$ glucan is a group of glucose polymers that consist of $\beta-1,3$ and the $\beta-1,6$ glycosidic linkages. It is a main cell wall structural component of fungi, plants and some bacteria (Jorgensen and Robertsen, 1995). It can activate lymphocyte, production of inflammatory cytokines and chemokines and microbial killing. This makes the adaptive immunity to be developed (Brown and Gordon, 2013; Brown et al., 2003). $\beta$ - glucan can stimulate leukocytes and neutrophil function, leading to increase resistance to diseases. This was reported in different animal species such as mammals, amphibians, fish and crustaceans. It has been found that a highly purified $\beta$ - 1,3/1,6-glucans in diets which extracted from baker's yeast, stimulate the humoral and cellular immune responses and increase disease resistance in many animal species (Sakai, 1999). 
Newcastle disease is one of the serious infectious diseases. There is no treatment for Newcastle disease yet, and vaccination is the only way for the control of the disease (Huang et al., 2004) vaccination is either by using active vaccines or inactivated vaccines. Components of the Fungal cell wall have been shown to have immunomodulating effects in humans and animals, and may have implicit as alternatives to antibiotic growth promoters for poultry - $\beta$ glucan production (Novak and Vetvicka, 2018; Thompson et al., 2019). Little information is available regarding the effect of adding - $\beta$ glucanto broiler diets on the immune status of broiler chickens. Based on this concept, this study was designed to evaluate the effect of $\beta$ glucan on innate and adaptive immune responses to routine vaccination with NDV and AIV vaccines, as well as oxidant/ antioxidant balance.

\section{Materials and methods}

\section{1. $\beta$-glucan:}

$\beta$-glucan was extracted from baker's yeast ( $S$. Cerevisiae) according to the method published by (Williams et al., 1991), and the modified method by (Chaunget al., 2009). The total concentration of carbohydrates present in the extract was determined according to the method (Dubois et al., 1956) that modified by (Masuko et al., 2015).

\subsection{Experimental Design:}

One hundred and eighty, 1-day-oldbroiler chicks (Hubbard local breed) of both sexes, were obtained from a local hatchery and divided into 3 groups 60 chicks each:

Group (1): Chicks fed on normal diet and kept as control.

Group (2): Chicks fed on normal diet mixed with $\beta$ glucan $200 \mathrm{mg} / \mathrm{kg}$ diet (low dose).

Group (3): Chicks fed on normal diet mixed with $\beta$ glucan $400 \mathrm{mg} / \mathrm{kg}$ diet (High dose).
All groups were vaccinated by bivalent AINDV vaccine at 7 day of age, then by Lasota vaccine at $21^{\text {st }}$ day of age.

\subsection{Blood Samples:}

Heparinized blood samples were taken (5 samples/group) at $5^{\text {th }} \& 12^{\text {th }}$ day post 1 st $\& 2^{\text {nd }}$ vaccination for separation of mononuclear cells used in phagocytic activity and for detection of malondialdehyde \& glutathione at the end of the experiment. Blood samples for serum separation were taken fromall groups (5 samples /group) at $2^{\text {nd }}$ day, $1^{\text {st }} \& 2^{\text {nd }}$ week post $1^{\text {st }}$ vaccination and $2^{\text {nd }}$ day, $1^{\text {st }}, 2^{\text {nd }}$ and $3^{\text {rd }}$ week post $2^{\text {nd }}$ vaccination, to detect and titrate antibodies against ND\& AI vaccine and for measurement of lysozyme and nitric oxide. The antibody titers against ND and AI $\mathrm{H} 9$ must be measured before vaccination to be ensured that the detected antibodies either high or low is due to the effect of vaccination not to the maternal antibodies.

\subsection{Evaluation of Innate Immunity:}

Assessment of innate immune response by evaluation of phagocytic activity, Lysozyme and nitic oxide production as the following:

\subsubsection{Assay of Phagocytosis:}

The test was performed according to (Bos and Souza, 2000), peripheral blood mononuclear cell layer was collected, washed and resuspended in RPMI-1640 media supplemented with $15 \%$ FCS. Then monolayer of macrophages was obtained by seeding $1 \mathrm{ml}$ $5 \times 106$ mononuclear cells in culture and staining chambers with cover slip and incubated for $1 \mathrm{hr}$ at $37^{\circ}$ in 5\% Co2 and $99 \%$ humidity. Removing the non-adherent cells by washing 3 times, then incubate for $24 \mathrm{hrs}$, after that the adherent macrophages were incubated at the same condition with $1 \mathrm{ml}$ Candida Albicans $\left(10^{7} / \mathrm{ml}\right.$ RPMI with 15\%FCS), washed 3 times, fixed and stained. Finally calculate the phagocytic\% (number of phagocytic macrophages/total number of macrophages) and phagocytic index (number 
of macrophages engulf $\geq 3$ Candida spores/total no of phagocytic macrophages.

\subsubsection{Lysozyme Assay:}

Lysozyme activity was measured by agarose gel plate lyses assay according to (Peeters and Vantrappen, 1977). Briefly, Lysoplates were prepared by dissolving $1 \%$ agarose in 0.06 mPBS at $\mathrm{pH} 6.3$ in which Micrococcus lysodeikticus ( $50 \mathrm{mg} / 100 \mathrm{ml}$ agarose) had been dispersed. Then $25 \mu \mathrm{l}$ of serum samples and standard lysozyme were added in each well. After 18 hours the cleared zones diameter were measured. The concentration of lysozyme was obtained from logarithmic curve prepared using standard lysozyme solution.

\subsubsection{Nitric Oxide Assay:}

Carried out according to (Jose et al., 1998 )and(Yang et al.,2010) briefly $100 \mu l$ of serum sample was mixed with $80 \mu 1$ of $375 \mathrm{mM}$ $\mathrm{ZnSO} 4$ and $120 \mu \mathrm{l}$ of $275 \mathrm{Mm} \mathrm{NaOH}$, then centrifuged at $13000 \mathrm{rpm}$ for $20 \mathrm{~min}$ to remove proteins. Supernatant was obtained and added to $400 \mathrm{mg}$ of $\mathrm{Cu}$ plated $\mathrm{Cd}$, then shook for $2.5 \mathrm{~h}$ at room temperature after adding $100 \mu \mathrm{l}$ of 0.2 M glycine buffer. $100 \mu$ Supernatant was added into 96-well ELISA plate then added $100 \mu 1$ of Griess reagent. The optical density was determined at $545 \mathrm{~nm}$ with an ELISA plate reader. Nitric oxide concentration was calculated from standard curve using NaNO2. 2.5. Evaluation of Humeral Immune Response: 2.5.1. Detection of Antibodies Titer to ND\&AI: Using Haemagglutination inhibition test (HI) according to (Beard, 1989).

The tested serum samples were serially diluted in PBS (Double fold dilution of $25 \mu 1$ volumes starting with $1 / 2$ dilution) using a $U$-shaped micro titer plate.

Twenty five $\mu$ l volumes containing 8 H.A. units of NDV or IV (prepared in PBS) were added to all individual wells of the diluted serum. Serum -virus mixture were allowed to stand at room temperature for 30 minutes to permit antigen - antibody reaction to occur.
Fifty $\mu l$ of $0.5 \%$ pre -washed chicken RBCs were added in the wells containing $8 \mathrm{H}$ A units of virus. The whole mixture was kept at room temperature for 30 minutes.

The wells containing $100 \mu \mathrm{l}$ of PBS $-\mathrm{RBCs}$ served as a negative control.

Antibody titer was determined as the reciprocal of the highest dilution of the tested serum that completely inhibits the heamagglutination of the cells with $8 \mathrm{H}$ A units of the virus (button like pattern).

\section{Quality Control}

- Known positive serum

- Known negative serum

- Serum and cells without antigen (to detect nonspecific agglutination)

- Back titration of hemagglutination activity of the antigen (to ensure that 8 hemagglutinating virus (HAU) were tested).

\subsubsection{Detection of Malondialdehyde and} Glutathione:

Malondialdehyde was measured according to (Ohkawaet al., 1979) and glutathione was measured according to (Ellman, 1959) at the end of experiment.

\subsection{Statistical analysis:}

Data obtained were statistically analyzed using analysis of variance and comparing between groups were performed using least significant difference (LSD) at $\mathrm{P}<0.05$ according to (Petrie and Watson, 1999) and computerized using SPSS.

\section{RESULTS}

In this study, we examined the effect of the $\beta$ glucan on Peripheral blood mononuclear cells, the phagocytic $\%$ \& index of broiler chickens (Table1) exhibited significant increase in groups (2) and(3) compared to control group at $5^{\text {th }}$ day post $1^{\text {st }} \& 2^{\text {nd }}$ vaccination. Also at $12^{\text {th }}$ day post $2^{\text {nd }}$ vaccination in group (3), receiving $400 \mathrm{mg}$ pure $\beta$ glucan $/ \mathrm{kg}$ diet (high concentration). 
Our results for lyzozyme (Table 2) showed significant increase at 2 day post $1^{\text {st }}$ vaccination in group 3 and at 2 weeks post 2 vaccinations in groups 2,3 comparing with control group.

Regarding to nitric oxide level in serum (Table 2) there is significant increase at $2^{\text {nd }}$ day post 1 st and $2^{\text {nd }}$ vaccination in groups $(2,3)$.

Concerning to humeral immune response, high dose of $\beta$ glucan (group3) improve the HI antibody titers for NDV and AIV comparing with that of control group surprised the result of group (2), broiler chickens fed on diet containing $200 \mathrm{mg} \beta$ glucan $/ \mathrm{kg}$ diet (low concentration), are fluctuated above and below that of the control group. We notice high level of maternal antibody for NDV and AIV which declined to negligible levels at 21 days of age (Table 3).

Regarding to the effect of $\beta$ glucan on oxidant and antioxidant status, there is a significant increase in GSH level and decrease in MDA level in $2 \& 3$ groups comparing to control group (Table 4).

Table1: Effect of the dietary supplementation of $\beta$ glucan on phagocytic $\% \&$ index of Peripheral blood mononuclear cells of broiler chickens.

\begin{tabular}{lllllll}
\hline & \multicolumn{3}{c}{ Phagocytic $\%$} & \multicolumn{3}{c}{ Phagocytic indix } \\
\cline { 2 - 7 } Parameterstime & Group1 & Group2 & Group3 & Control & Low & High \\
\hline $5^{\text {th }}$ day post 1st vac. & $54 \pm 1.67 \mathrm{~A}$ & $59 \pm 0.33 \mathrm{Ba}$ & $65 \pm 0.88 \mathrm{Ca}$ & $0.40 \pm 0.03 \mathrm{~A}$ & $0.56 \pm 0.02 \mathrm{Ba}$ & $0.62 \pm 0.02 \mathrm{Ca}$ \\
$1^{\text {th }}$ day post 1st vac & $53 \pm 1.22$ & $54 \pm 3.18 \mathrm{~b}$ & $55 \pm 2.40 \mathrm{~b}$ & $0.37 \pm 0.04$ & $0.36 \pm 0.051 \mathrm{~b}$ & $0.41 \pm 0.05 \mathrm{~b}$ \\
$5^{\text {th }}$ day post 2nd vac. & $55 . \pm 1.86 \mathrm{~A}$ & $61 \pm 0.33 \mathrm{Bac}$ & $66 \pm 0.67 \mathrm{Cac}$ & $0.41 \pm 0.03 \mathrm{~A}$ & $0.60 \pm 0.01 \mathrm{Bac}$ & $0.62 \pm 0.02 \mathrm{Ba}$ \\
$12^{\text {th }}$ day post 2nd vac & $54 \pm 1.67 \mathrm{~A}$ & $56 \pm 0.98 \mathrm{Aab}$ & $62 \pm 0.36 \mathrm{Bad}$ & $0.43 \pm 0.04 \mathrm{~A}$ & $0.41 \pm 0.02 \mathrm{Abd}$ & $0.58 \pm 0.02 \mathrm{Ba}$ \\
LSD & 4 & & & 0.05 & & \\
\hline
\end{tabular}

Means with different capital letters are significant different between groups

Means with different small letters are significant different between time intervals

Table 2: Effect of the dietary supplementation of $\beta$ glucan on Serum lysozyme $(\mu \mathrm{g} / \mathrm{ml})$ and nitric oxide $(\mu \mathrm{mol} / \mathrm{ml})$ of broiler chickens.

\begin{tabular}{ccccccc}
\hline \multirow{2}{*}{ Parameterstime } & \multicolumn{2}{c}{ Lysozyme } & \multicolumn{3}{c}{ Nitric oxide } \\
& Group1 & Group2 & Group3 & Group1 & Group2 & Group3 \\
\hline $2^{\text {nd }}$ day post 1st vac. & $9.27 \pm 1.23 \mathrm{Aa}$ & $11.12 \pm 0.58 \mathrm{a}$ & $15.5 \pm 0.98 \mathrm{Ba}$ & $20.36 \pm 0.33$ & $19.90 \pm 0.58 \mathrm{a}$ & $21.40 \pm 0.64 \mathrm{a}$ \\
& $18.76 \pm 1.87 \mathrm{~b}$ & $20.93 \pm 1.59 \mathrm{~b}$ & $19.56 \pm 1.34 \mathrm{~b}$ & $18.96 \pm 0.73 \mathrm{a}$ & $18.96 \pm 0.07 \mathrm{a}$ & $20.33 \pm 0.58 \mathrm{a}$ \\
$1^{\text {st }}$ week post 1st vac & $23.74 \pm 0.87 \mathrm{c}$ & $26.85 \pm 4.77 \mathrm{c}$ & $24.95 \pm 2.77 \mathrm{c}$ & $21.33 \pm 1.71 \mathrm{Ab}$ & $24.62 \pm 1.10 \mathrm{Bb}$ & $26.70 \pm 0.26 \mathrm{Cb}$ \\
$2^{\text {nd }}$ day post 2nd vac. & $32.72 \pm 2.18 \mathrm{~d}$ & $32.75 \pm 2.52 \mathrm{~d}$ & $33.28 \pm 4.11 \mathrm{~d}$ & $18.90 \pm 2.03 \mathrm{a}$ & $19.43 \pm 0.98 \mathrm{a}$ & $20.09 \pm 0.36 \mathrm{a}$ \\
$1^{\text {st }}$ week post 2nd vac & $33.96 \pm 2.19 \mathrm{Ad}$ & $43.68 \pm 3.97 \mathrm{Ba}$ & $46.65 \pm 3.61 \mathrm{Ce}$ & $20.13 \pm 1.35$ & $21.26 \pm 0.03 \mathrm{a}$ & $21.03 \pm 0.76 \mathrm{a}$ \\
$2^{\text {nd t }}$ week post 2nd vac & 5.41 & & & & & \\
LSD & & & & & &
\end{tabular}

Means with different capital letters are significant different between groups

Means with different small letters are significant different between time intervals 
Table 3: Effect of the dietary supplementation of $\beta$ glucan on HI titer of NDV and AIV in broilers chickens.

\begin{tabular}{lcccccc}
\hline \multirow{2}{*}{ Parameter's time } & \multicolumn{3}{c}{ NDV } \\
\cline { 2 - 7 } & Group 1 & Group 2 & Group 3 & Group 1 & Group 2 & Group 3 \\
\hline 0 day & $7.2 \pm 0.16 \mathrm{Ca}$ & $4.80 \pm 0.25 \mathrm{~A}$ & $5.20 \pm 0.25 \mathrm{~A}$ & $5.40 \pm 0.16 \mathrm{~A}$ & $5.39 \pm 0.26 \mathrm{~b}$ & $5.43 \pm 0.27 \mathrm{~b}$ \\
$7^{\text {th }}$ day post $1^{\text {st }}$ vac. & $4.20 \pm 0.25 \mathrm{~b}$ & $4.29 \pm 0.23 \mathrm{Ba}$ & $4.9 \pm 0.61 \mathrm{Ca}$ & $3.40 \pm 0.15 \mathrm{~A}$ & $4.0 \pm 0.25 \mathrm{Ba}$ & $4.2 \pm 0.17 \mathrm{Ca}$ \\
$14^{\text {th }}$ day post $1^{\text {st }}$ vac. & $4.6 \pm 0.28 \mathrm{Ba}$ & $5.1 \pm 0.38 \mathrm{~b}$ & $5.8 \pm 1.40 \mathrm{~b}$ & $3.00 \pm 0.21 \mathrm{~A}$ & $2.89 \pm 0.21 \mathrm{~b}$ & $3.15 \pm 0.15 \mathrm{~b}$ \\
$1^{\text {st }}$ week post $2^{\text {nd }}$ vac. & $7.1 \pm 0.26 \mathrm{~A}$ & $6.7 \pm 0.31 \mathrm{Bac}$ & $7.9 \pm 0.54 \mathrm{Cac}$ & $3.20 \pm 0.19 \mathrm{~A}$ & $3.01 \pm 0.19 \mathrm{Bac}$ & $5.43 \pm 0.61 \mathrm{Ba}$ \\
$2^{\text {nd }}$ week post $2^{\text {nd }}$ vac. & $7.4 \pm 0.22 \mathrm{~A}$ & $7.8 \pm 0.48 \mathrm{Aab}$ & $8.2 \pm 0.34 \mathrm{Bad}$ & $5.10 \pm 0.20 \mathrm{~A}$ & $5.00 \pm 0.22 \mathrm{Abd}$ & $5.60 \pm 0.12 \mathrm{~A}$ \\
$3^{\text {rd }}$ week post $2^{\text {nd }}$ vac. & $7.5 \pm 0.20 \mathrm{~b}$ & $7.7 \pm 0.27 \mathrm{~A}$ & $8.4 \pm 029 \mathrm{~b}$ & $5.12 \pm 0.24 \mathrm{~A}$ & $5.18 \pm 0.24 \mathrm{~A}$ & $6.98 \pm 0.26 \mathrm{~b}$ \\
\multicolumn{1}{c}{$\mathrm{LSD}$} & 1.2 & & & 0.09 & & \\
\hline
\end{tabular}

Means with different capital letters are significant different between groups

Means with different small letters are significant different between time intervals

Table 4: Effect of the dietary supplementation of $\beta$ glucan on Glutathione and Malondialdehyde.

\begin{tabular}{lcc}
\hline Parameters-groups & Glutathione Mmol/l & Malondialdehyde Mmol/l \\
\hline Group 1 & $3.82 \pm 0.09 \mathrm{a}$ & $16.19 \pm 0.02 \mathrm{a}$ \\
Group 2 & $4.43 \pm 0.05 \mathrm{~b}$ & $10.63 \pm 0.31 \mathrm{~b}$ \\
Group 3 & $4.49 \pm 0.09 \mathrm{~b}$ & $11.23 \pm 0.34 \mathrm{~b}$ \\
\hline
\end{tabular}

Means with different small letters are significant different between groups

\section{DISCUSSION}

Recent researches and development of $\beta$ glucan products have been increasingly focused on functional benefits including resistance to gastrointestinal bacterial infection and improved immune status in broiler chicks. The consumption of a probiotic in combination with a suitable prebiotic ( $\beta$ glucan) can result in synergistic effects (Zanoni et al., 2008).

In this study, we examined the effect of the $\beta$ glucan on Peripheral blood mononuclear cells, the phagocytic $\%$ \& index of broiler chickens (Table1) exhibited significant increase in groups (2) and(3) compared to control group at $5^{\text {th }}$ day post $1^{\text {st }} \& 2^{\text {nd }}$ vaccination. Also at $12^{\text {th }}$ day post $2^{\text {nd }}$ vaccination in group (3), receiving $400 \mathrm{mg}$ pure $\beta$ glucan $/ \mathrm{kg}$ diet (high concentration). These results agree with previous findings (Schiffrin et al., 1997; Panigrahi et al., 2014; Diaz-Rosales et al., 2016) which recorded that probiotic including $\beta$ glucan increases the activities of phagocytes, also with (Shimada et al., 2009) who reported that $\beta$ glucan act on macrophages activity in a dose dependent manner. The activities of phagocyte may be explained as, the bacterial cell or bioactive peptide released during fermentation by lactic acid bacteria activate the immune response through a dynamic interaction with specific Toll-like receptors on the surface of macrophage (it was known that the phagocytosis by macrophages is Toll-like receptors dependent) this interaction between host cells and pathogens or their structural components may play a critical role in the early innate immune response. The activation of the TLRs starts signaling cascades that involve the activation of proteins and transcription factors inducing the secretion of proinflammatory \& effectors cytokines which farther activate macrophage cells (Blander and Medzhitov, 2004).

Lysozyme was known to be one of Lysosomal enzyme which attacks mucopeptide in cell 
walls of various bacteria and a member of innate humeral factors that elaborated from polymorph nuclear and mononuclear cells (Moore et al., 2006). Our results (Table 2) showed significant increase at 2 day post 1 vaccination in group 3 and at 2 weeks post 2 vaccinations in groups 2,3 comparing with control group. These results are in agreement with (Schiffrin et al., 1997) and (Weir, 1983) who recorded that, the $\beta$ glucanincreases the activities of lysozyme due to activation of phagocytic macrophage.

Regarding to nitric oxide level in serum (Table 2) there is significant increase at $2^{\text {nd }}$ day post 1 st and $2^{\text {nd }}$ vaccination in groups $(2,3)$. Nitric oxide is generated during immune and inflammatory response; it is involved in innate immunity as a toxic agent towards infectious organisms and can induce or regulate death and function of host immune cells (Coleman, 2011). It is produced at high levels by macrophages through its activation (Aouatef $e t$ al., 2002).

Concerning to humeral immune response, high dose of $\beta$ glucan (group3) improve the HI antibody titers for NDV and AIV comparing with that of control group while the result of group (2), broiler chickens fed on diet containing $200 \mathrm{mg} \beta$ glucan $/ \mathrm{kg}$ diet (low concentration), are fluctuated above and below that of the control group. We notice high level of maternal antibody for NDV and AIV which declined to negligible levels at 21 days of age. These results are in agreement with that of (Maassen et al., 2000) who recorded that, oral administration of $\beta$ glucanis significally enhance $\operatorname{IgG}$ response, also to (Haghighi et al., 2016) who found that $\beta$ glucan enhance the systemic antibody response to some antigens in chickens and (Talebi et al., 2008) who found that administration of $\beta$ glucan improve the antibody responses to ND. It is possible that, binding of structural components of Commencal bacteria to Toll-like receptors (TLRS) expressed on the surface of

macrophage and dendritic cells in the lamina propria may lead to their activation and differentiation. Upon its activation, they promote the activation and differentiation of different subsets of other immune system cells, leading to the production of cytokines such as IL4, IL10 and transforming growth factor B, that are important for antibody production and isotope switching (Di Giacinto et al., 2005; Mohamadzadeh et al., 2005). Regarding to the effect of $\beta$ glucan on oxidant and antioxidant status, there is a significant increase in GSH level and decrease in MDA level in $2 \& 3$ groups comparing to control group (Table 3 ). Our results may be due to antioxidative activity of polysaccharides (constituent of $\beta$ glucan), these results were partially agree with studies that described antioxidative activity of yeast cell wall polysaccharides (Songisepp et al.,2004; Kullisaar et al.,2012) and are confirmed by (Kai Truusalu et al.,2008) who showed that the administration of the mannanoligosaccharide significantly reduce MDA values. Also by (Hutt et al., 2009) that showed increase of GSH after the consumption of the $\beta$ glucan.

\section{Conclusion}

This study provides evidence that the oral administration of $\beta$ glucan (low \& high doses) to broiler chickens early in life enhances innate immunity which represented by significantly increase phagocytic activity, lysozyme activity and nitric oxide in dose dependent manner. The administration of $\beta$ glucan in high dose improves humeral immune response represented by increase antibody response to NDV and AIV vaccines. The administration of $\beta$ glucan in both doses improved the oxidative state of broiler chickens by increase GSH and decrease MDA due to antioxidative activity of the used product.

\section{REFERENCES}


Aouatef, D., M. Eugene, B. Nelly, V. Yves and Q. Pascale, (2002). Similar pattern of expression, No production and cytokine response in genetic and vaccinationacquired resistance to Marek, disease. Vet. Imm. and Immunopatho., 85: 63-75.

Beard, C.W., (1989). Serological procedures. In: Laboratory manual for the isolation and identification of avian pathogens published by the American Association of avian pathologists, 3 ED., pp: 192200.

Blander, J.M. and R. Medzhitov, (2004).Regulation of phagosome maturation by signals from toll-like receptors. Sci., 304: 1014-8.

Bos H, de Souza W. (2000). Phagocytosis of yeast: a method for concurrent quantification of binding and internalization using differential interference contrast microscopy. 238(12):29-43.

Brown, G. D. and Gordon, S. (2013). Fungal $\beta$ -glucans and mammalian immunity. Immunity 19: 311-315.

Brown, G. D., Herre, J., Williams, D. L., Willment, J. A., Marshall, A. S. J. and Gordon, S. (2003). Dectin-1 mediates the biological effects of $\beta$-glucans. J. Exp. Med. 197: 1119- 1124.

Chaung, H.C., Huang, T.C., Yu, J.H., Wu, M.L., Chung, W.B. (2009). Immunomodulatory effects of bglucans on porcine alveolar macrophages and bone marrow haematopoietic cell-derived dendritic cells. Veterinary Immunology and Immunopathology 131,147-157.

Coleman, J.W., (2011). Nitric oxide in immunity and inflammation.
International Immunopharmacol., 1: 1397-1406.

Di Giacinto, C., M. Marinaro, M. Sanchez, W. Strober and M. Boirivant, (2005). Probiotics ameliorate recurrent Th1mediated murine colitis by inducing IL10 and IL 10 dependant TGF-betabearing regalatory cells. J. Immunol., 174: 3237-3246.

Diaz-Rosales.P., I. Salinas A. Rodriguez, A. Cuesta, M. Chabrillon and M.C. Balebona, (2016).Gilthead seabream (Sparusaurata L.) innate immune response after dietary administration of heat-inactivated potential probiotics. Fish and Shellfish Immunol., 20: 48292.

Dubois, M., Gilles, K. A., Hamilton, J. K., Rebers, P. A., and Smith, F. (1956).Colorimetric method for determination of sugars and related substances. Anal. Chem. 28:350-356.

Ellman, G. L. (1959). Tissue sulfdryl groups. Arch Biochem. Biophys, 82: 70-77.

Haghighi, H.R., J. Gong, C.L. Gyles, M.A. Hayes, H. Zohu, B. Sanei, J.R. Chambers and S. Sharif, (2016). Probiotics stimulate production of natural antibodies in chickens. Clinical and Vaccine Immunol., 13(9): 975-980.

Huang, Z., Subbaih,F.,Abdul, S.Y. and Siba,K.S. (2004). A recombinant Newcastle virus (NDV) expressing VP2 protein of infectious Bursal Disease Virus (IBDV) Protect against NDV and IBDV. J. Virol., 78: 10054-10063.

Huff, G.R., Huff, W.E., Rath, N.C. and Tellez, G. (2016). Limited treatment with $\beta-1$, $3 / 1$, 6-Glucan improves production values of broiler chickens challenged 
with Escherichia coli. Poultry Science, 85: 613-618.

Hutt, P., H. Anderson, T. Kullisaar, E. Vihalemm, E. Unt, J. Kals, P. Kampus, M. Zilmer and M. Mikelsaar, (2009). Effects of $\beta$ glucan product on blood antioxidative activity in subjects colonized with Helicobacter pylori. Letters in Appl. Microbiol., 48: 797-800.

Jorgensen, J. B. and Robertsen, B. (1995). Yeast beta-glucan stimulates respiratory burst activity of Atlantic salmon (Salmosalar L.) macrophages. Dev. Comp. Immunol. 19: 43- 57.

Jose A. Navarro-Gonzalvez, Cristina GarciaBebayas and Joaquin Arenas, (1998). Semiautomated measurement of nitrate in biological fluids. Clinical Chemistry, 44(3): 679-681.

Kai Truusalu, Raik-HiioMikelsaar, Paul Naaber, TonisKarki, TiiuKullisaar, MihkelthZilmer and MarikaMikelsaar, (2008). Eradication of salmonella Typhimurium infection in a murine model of typhoid fever with the combination of pribiotic Lactobacillus fermentum ME- 3 and ofloxacin. BMC Microbiol., 8: 132.

Kullisaar, T., M. Zilmer, M. Mikelsaar, T. Vihalemm H. Annuk, C. Kairane and A. Kilk, (2012). Two antioxidative lactobacilli strains as promising pribiotics. Int. J. Food Microbial., 72: 215-224.

Leung, MYK, Liu, C, Koon, JCM and Fung, KP. 2006. Polysaccharide biological response modifiers. Immunology Letters, 105: 101-114.

Maassen, C.B.C., Van Holten-Neelen, F. Balk, M.J. DenBak-Glashouewer, R.J. Leer, J.D. Laman, W.J. Boersma and E.
Claassen, (2000). Strain dependent Induction of cytokine profiles in the gut by oral administered Lactobacillus strains Vaccine. 18(23):2613-23.

Masuko,T., Minami,A., Iwasaki, N., Majima,T., Nishimura, S.I. and, Lee, Y. C. (2015). Carbohydrate analysis by a phenol-sulfuric acid method in microplate format. Analytical Biochemistry, 339(1): 69-72.

Mohamadzadeh, M., S. Olson, W. Kalina, G. Ruthel, G.L. Demmin, K.L. Warfield, S. Bavari and T.R. Klaenhammer, (2005). Lactobacilli activate human dendritic cells that shew $\mathrm{T}$ cell toward $\mathrm{T}$ helper 1 polarization. Proc. Natl. Acad. Sci. USA, 102: 2880-2885.

Moore, M.M., J.I. Allen and A. Mcveigh, (2006). Environmental prognostic: an integrated modal supporting lysosomal stress as predictive biomarkers of animal health status Marine Environmental Res., 61: 278-304.

Novak, M and Vetvicka, V. (2017). Glucans as biological response modifiers. Endocrine, Metabolic, \& Immune Disorders - Drug Targets, 9: 67-75.

Novak, M. \&Vetvicka, V. (2018). Beta-glucans, history, and the present: immunomodulatory aspects and mechanisms of action. Journal of Immunotoxicology, 5: 47-57.

Ohkawa, H., N. Ohishi and K. Yagi, (1979). Assay for lipid peroxides in animals tissues by thiobarbituric acid reaction. Anal Biochem., 95: 351-358.

Panigrahi, A., V. Kiron, T. Kobayashi, J. Puangkaew, S. Satoh and H. Sugita, (2014). Immune response in rainbow trout Oncorhynchusmykiss induced by a potential probiotic bacteria 
Lactobacillus rhamnosus JCM 1136.

Veterinary Immunol. and Immunopathol., 102(4): 379-88.

Peeters T.L. and G.R. Vantrappen, (1977).Factors influencing lysozyme determination by lysoplate method.Cli. Chim. Acta, 74: 217-255.

Petrie, A. and P. Watson, (1999).Statistics for Veterinary and Animal Science. 1 Ed., the Blackwell science Ltd, United Kingdom, pp: 90-99.

Sakai, M. (1999).Current research status of fish immunostimulants. Aquaculture 172: 63-92.

Schiffrin, E.J., D. Rassart, A.L. Servin, F. Rochat and A. Donnet Hughes, (1997). Immune modulation of blood leukocytes in humans by lactic acid bacteria: criteria for strain selection. American J. Clinical Nutrition, 66: 515520.

Shimada, T., Yuning Cai, Lei Cheng, Chie Motonaga, KazutakeFukada, Yoshihisa Kitamura and Jieshu Wu, (2009). Immunomodulation effects of heattreated Enterococcus faecalis FK23(FK-23) in Mice, 23(3): 173-176.

Soltanian, S, Stuyven, E, Cox, E, Sorgeloos, P and Bossier, P. (2009).Beta-glucans as immunostimulant in vertebrates and invertebrates. Critical Reviews in Microbiology, 35: 109-138.

Songisepp, E., T. Kullisaar, P. Hutt, P. Elias, T. Brilene, M. Zilmer and M. Mikelsaar, (2004).A new probiotic cheese with antioxidative and antimicrobial activity.

J. Dairy Sci., 87: 2017-2023.

Talebi.A., B. Amirzadeh, B. Mokhtari and H. Gahri, (2008). Effects of a multi-strain probiotic (PrimaLac) on performance and antibody responses to Newcastle disease virus and infectious bursal disease virus vaccination in broiler chickens. Avian Pathol., 37(5): 509-512.

Thompson, I.J., Oyston, P.C. \& Williamson, D.E. (2019).Potential of the betaglucans to enhance innate resistance to biological agents. Expert Reviews in Anti Infection Therapy, 8: 339-352.

Volman, J.J., Ramakers, J.D. and Plat, J. (2018).Dietary modulation of immune function by $\beta$-glucans. Physiology and Behaviour, 94(2): 276-284.

Weir, D.M., (1983). Immunology: an outline for students of medicine and biology: 5 Ed., Churchil Livingstone, London. Melbourne, New York, pp: 15-16.

Williams, D.L., McNamee, R.B., Jones, E.L., Pretus, H.A., Ensley, H.E., Browder, I.W., Di Luzio, N.R. (1991). A method for the solubilizationofa (1!3)-beta-Dglucan isolated from Saccharomyces cerevisiae. Carbohydr. Res. 219, 203213.

Yang, M.D., M.B. RazaAsim, M.S.C. Xiaogang Jiang, M.D. Bo Zhong, M.D. Muhammad Shahzad, Fujun Zhang and M.D. Lu Shemin, (2010). Nitric oxide in both bronchoalveolar lavage fluid and serum is associated with pathogenesis and severity of antigen-induced pulmonary inflammation in rats. $\mathrm{J}$. Asthma, 47: 135-14.

Zanoni, S., A. Pompei, L. Cordisco, A. Amaretti, M. Rossi and D. Matteuzzi, (2008). Growth kinetics on oligo- and polysaccharides and promising features of three antioxidative potential probiotic strains. J. Appl. Microbiol., 105: 1266-12. 